\title{
Laporan Harian/mingguan Minggu ke VII
}

\author{
Nama : Arfiana safitri \\ Posko : Tolo' Timur \\ Tempat Kegiatan : Kelurahan Tolo' Timur \\ Nim : 9173490210042 \\ Email: Arfianasafitri96@gmail.com
}

1. Bentuk Kegiatan

-Pengajaran TK TPA

2. Lokasi

-Setiap mesjid lingkungan Tolo

Timur

3. Hari / tanggal dan waktu

- sabtu, 31 oktober 2020

4. Peserta yang di libatkan

-Mahasiswa dan Santri

5. Alasan di adakannya

Alasan di adakannya pengajaran

TK/TPA supaya kita tidak lupa

akan pedoman hidup kita sebagai

umat islam

6. Tujuan dan manfaat

Setiap kegiatan yang dilakukan bertujuan untuk kebaikan masyarakat Tolo Timur dan memperlihatkan bahwa program kami sangat berdampak positif oleh masyarakat kelurahan Tolo Timur.

\section{Deskripsi kegiatan}

Kegiatan ini bertujuan untuk mengenal lebih jauh pedoman hidup kita 